\title{
Planering, progression, profession: hur studenter blir planerare
}

\author{
Lars Larsson* \\ Institutionen för geografi och ekonomisk historia, Umeå universitet
}

\begin{abstract}
De kunskaper som utvecklas med stöd i de nationella examensmålen för värderingsförmåga och förhållningssätt är de som ligger närmast den professionella identiteten. Denna kunskapskategori ges begränsat utrymme i de förväntade studieresultat som examineras inom samhällsplanerarprogrammet vid Umeå universitet. Trots detta får studenterna anställning som planerare, ofta kort efter att de tagit sin kandidatexamen. Syftet med denna studie är därför att undersöka hur kunskapsmässig progression underbyggs avseende värderingsförmåga och förhållningssätt i en planerarutbildning med kulturgeografi som huvudområde. I denna artikel redovisas en analys av samhällsplanerarprogrammet.

De kurser i kulturgeografi som ingår i programmet analyseras utifrån förväntade studieresultat, läraktiviteter och examinationsformer i syfte att spåra den planerade progressionen. Särskild uppmärksamhet ägnas kunskapskategorin värderingsförmåga och förhållningssätt. Resultaten diskuteras utifrån en modell för att förstå vilka typer av kunskaper som används vid avvägningar och beslut i planeringsprofessionen. Analysen visar att samhällsplanerarprogrammets planerade progression följer principen att först ge studenterna breda ämneskunskaper, därefter utveckla metodfärdigheter och mot slutet utveckla mer komplexa och handlingsinriktade kunskaper. Den visar också att den planerade progressionen är begränsad i att underbygga normativa aspekter av studenternas värderingsförmåga och förhållningssätt.
\end{abstract}

Keywords: kunskapsformer, planerad progression, förväntade studieresultat, kandidatprogram, planering

Lär vi studenterna vid Umeå universitets samhällsplanerarprogram att planera? Det uppenbara svaret är - ja! De deltar aktivt i och examineras på planeringsinriktade kurser inom programmet, de tar ut examen och merparten av de utexaminerade studenterna får anställning som planerare (Lindström \& Mackay, 20I4). Studenterna kan därmed sägas förstå och behärska teoretiska idéer inom fältet, de kan tillämpa vetenskapliga teorier i komplexa yrkessammanhang och de reflekterar över handlingar och värden som genomsyrar professionen. Studenterna har också en grundförståelse för planeraryrkets professionella normer - de förståelser, ord och handlingar som genomsyrar den professionella identiteten (Hoch, I992; Smeby, 2007; Reid m.fl., 2008; Trede m.fl., 20I2). Studenterna har kort sagt utvecklat viktiga delar i den professionella kunskapsbasen och identiteten.

Här kan invändas att professionell identitet inte är ett nödvändigt kriterium för att få anställning som planerare, eller vilket annat yrke som helst. Det tycks inte heller studenterna anse. De betraktar universiteten i första hand som miljöer för undervisning och lärande, medan den professionella identiteten i huvudsak etableras efter examen (Trede m.fl., 20I2). Studentens situation

* Författarkontakt: Lars Larsson, lars.larsson@umu.se

Artiklar och reflektioner är kollegialt granskade. Övriga bidragstyper granskas av redaktionen. Se www.hogreutbildning.se ISSN 2000-7558

(C)2017 Lars Larsson. This is an Open Access article distributed under the terms of the Creative Commons Attribution-NonCommercial 4.0 International License (https://creativecommons.org/licenses/by-nc/4.0/), allowing third parties to share their work (copy, distribute, transmit) and to adapt it, under the condition that the authors are given credit, that the work is not used for commercial purposes, and that in the event of reuse or distribution, the terms of this license are made clear.

Citation: Lars Larsson (2017) "Planering, progression, profession: hur studenter blir planerare», Högre utbildning 7, 85-97. http://dx.doi. org/10.23865/hu.v7.974 
skiljer sig på många sätt - exempelvis mentalt, organisatoriskt och ekonomiskt - från den professionella planerarens, men kunskapsmässigt bör de ligga nära varandra. Kunskapen möjliggör övergången till yrkeslivet. Av de tre kunskapskategorierna i svensk högre utbildning är kategorin "värderingsförmåga och förhållningssätt" (SFS I993:IOO, bilaga 2; se figur 2) den som ansluter tydligast till den professionella identiteten. Värderingsförmåga och förhållningssätt är "personlig[a] och kräver ställningstagande och självkännedom” (Elmgren \& Henriksson, 20IO, s. 28).

Syftet med denna studie är därför att undersöka hur kunskapsmässig progression underbyggs avseende värderingsförmåga och förhållningssätt $\mathrm{i}$ en planerarutbildning med kulturgeografi som huvudområde. I fokus är den planerade progressionen i form av kunskapsmål, examinationsformer och läraktiviteter, den formella stommen för samhällsplanerarprogrammet (Fraser \& Bosanquet, 2006). Mer konkret ställs följande frågor:

- Vilka kunskapsmål i form av förväntade studieresultat (FSR) i kategorin värderingsförmåga och förhållningssätt innehåller programmet och vilka kunskaper syftar de till att utveckla?

- Vilka läraktiviteter och examinationsformer kopplas till de kunskapsmålen?

- Hur stärker dessa förmågan att utveckla en professionell identitet?

Samhällsplanerarprogrammet ger en examen i kulturgeografi med inriktning samhällsplanering. Programmet omfattas alltså av de generella examensmålen, men har ändå en relativt tydlig professionsinriktning. Balansen mellan ämnes- och professionsinriktning i fråga om programinnehåll tycks ha fallit väl ut. Sedan programmets tillkomst år 2007 har det varit stabilt i sin grundstruktur och i tillströmning och genomströmning av studenter. Programmet har en fungerande faktisk progression - åtminstone att döma av att studenterna anställs som planerare, vilket gör programmets planerade progression relevant att analysera.

I artikeln används teorier om professionell identitet i relation till högre utbildning och planeringsteori med planerarrollen i särskilt fokus. De presenteras härnäst. Empirin hämtar jag från en analys av samhällsplanerarprogrammets formella dokument så som utbildningsplan, kursplaner och beskrivningar av läraktiviteter och examinationer samt från intervjuer med kursansvariga lärare på programmet. Slutsatser och diskussion avslutar artikeln.

\section{PROFESSIONELL IDENTITET OCH KUNSKAPSANVÄNDNING I PLANERING}

Planerares uppdrag är att medverka i skapandet av bättre platser, ofta handlar det om stadsmiljöer (Campbell, 20I2; Healey, 20IO; Luukkonen, 20II). Platser förändras ständigt genom mångfalden av aktörer som strävar efter att förverkliga sina intressen. För att förstå och hantera denna platsernas dynamik krävs uppmärksamhet på:

[...] händelsekedjor, som skapas av enskilda projekt och aktiviteter, och hur de vävs samman över tid och rum. Det kräver överväganden kring hur relationerna ser ut mellan de olika dimensionerna i våra liv - hem, arbete, fritid etc. - och hur vi rör oss mellan dem. Det kräver inte bara uppmärksamhet på våra egna intressen, utan även på de komplexa, ömsesidiga beroenden och skyldigheter vi har med andra människor, andra platser och andra tidsperioder i det förflutna och i framtiden. (Healey, 20IO, s. 20, min översättning)

I den mångdimensionalitet som platser kännetecknas av förväntas planerare fatta beslut. De förväntas leda till effektiv och legitim användning av mark, vatten och andra gemensamma 
resurser för individer, hushåll, företag och organisationer (Berger \& Forsberg, 20I3; Fischler, 20I2). Det kräver kunskap om vilka frågor och erfarenheter, möjligheter och konflikter som påverkar det enskilda projektet (Healey, 20IO). Kartor, statistik och andra analyser är vanliga kunskapsunderlag i planeringsutredningar och vid beslut. Medborgarnas levda erfarenheter från skilda sociala och kulturella sammanhang kompletterar och komplicerar underlagen (Arnstein, 1969; Innes, 1998).

Själva tiden är ytterligare en dimension i planeringsarbetet. Planerare förväntas i nuet göra avvägningar i fråga om vilka åtgärder som är rimligast utifrån ofullständig kunskap om det förflutna och med osäkerhet kring beslutens framtida konsekvenser (Campbell, 20I2; Olsson, 1990). Eftersom besluten handlar om den rumsliga miljön - byggnader, vägar, industriområden och andra strukturer - får utfallen ofta långvariga konsekvenser.

Det är med andra ord höga analytiska och värderingsmässiga krav som ställs på planerare. Perspektivgörande förmågor som kännedom om planerings- och samhällsteorier, om de bidrag olika analysmetoder kan ge samt förmåga att reflektera kring planering och planerarens roll är därför avgörande.

Campbell (20I2) föreslår en kategorisering av vad planerare gör utifrån vilken typ av kunskap de använder i sin professionella verksamhet. I varje avvägning och beslut, hävdar Campbell, måste åtminstone fyra frågor besvaras - medvetet och uttalat eller internaliserat $i$ kunskapsprocessen. De fyra frågorna besvaras med bruk av fyra generella kunskapsformer. Kunskapsformerna paras ihop till två dimensioner:

$\begin{array}{lll}\text { Vad pågår här? } & \rightarrow & \text { Vad ska göras? } \\ \text { Deskriptiv kunskap } & & \text { Preskriptiv kunskap } \\ \text { Varför är det så? } & \rightarrow & \text { Vad borde göras? } \\ \text { Analytisk kunskap } & \rightarrow & \text { Normativ kunskap }\end{array}$

Dimensionen deskriptiv (beskrivande) och preskriptiv (föreskrivande) kunskap handlar främst om kunskap och handling inom existerande system och tillvägagångssätt. Den analytisk-normativa dimensionen handlar mer om att utveckla eller förändra rådande föreställningar och förhållningssätt. Campbell (2012) argumenterar vidare för att inom forskning och undervisning vid universiteten dominerar de deskriptiva och analytiska kunskapsperspektiven, alltså kunskapsformerna till vänster i uppställningen ovan. Preskriptiv och normativ kunskap ges mindre utrymme. Det finns också en obalans i det att de förra i första hand är: "inriktade på analys - att förstå hur världen är eller kan bli - inte inriktade på syntes - hur man kan nå fram till övervägda beslut om hur världen borde vara" (Campbell, 20I2, s.I4O, min översättning, kursiv i original).

Analysarbetet förvandlar sammanhang till delar som återskapas till förklarade helheter. Det förutsätter ett tillbakablickande perspektiv; något redan passerat förklaras i efterhand. Syntesarbetet strävar istället efter klarhet i det komplexa genom resonemang. Resonemangen hämtar kunskap ur det förflutna, men är i motsats till analysarbetet framåtblickande; de bidrar till att skapa förutsättningar för värderingsbaserade beslut, att rättfärdiggöra det som bör göras och att avgöra vad som behöver göras för att nå dit (Campbell, 20I2). Snarare än att skapa förklaringar är ambitionen med synteser att möjliggöra förändring. Strävan efter förändring aktiverar frågor av etisk art. Vilken, om någon, förändring är eftersträvansvärd? Hur ska förändringen uppnås? För vilka? Analyser är nödvändiga men inte tillräckliga underlag för att hantera de här frågorna. 
Campbell (2006) konstaterar att själva strävan med planering är förändring. När offentliga aktörer planerar är avsikten ofta (ökad) framtida rättvisa för flertalet. Frågor om rättvisa är inte värdeneutrala. De påverkas av hur, och av vilka, planering görs. "Practical reasoning" - ett omdömesgillt, målinriktat samtal - baserat på kunskap, förståelse och erfarenhet kan bidra till ökad rättvisa (Campbell, 2006, s. IO2). Ett resonerande arbetssätt med många aktörer och intressen inblandade kräver rimligtvis förmåga till kritisk reflektion (Lucas \& Tan, 20I3). Det kritiska reflekterandet bidrar till förändringar i människors meningsskapande och grundläggande förståelser av världen, vilket i förlängningen kan skapa ett tillstånd av "critical being" som grund för handling (Barnett, 1997; Lucas \& Tan, 2013). Det handlar sammantaget om den värderingsförmåga och de förhållningssätt med krav på ställningstagande och självkännedom som högskoleförordningen ger universitet och högskolor uppdraget att utveckla (Elmgren \& Henriksson, 2010; Ramsden, 2003; SFS 1993:100).

\section{PROGRESSION MOT PROFESSION}

Det ligger nära till hands att tänka att värderingsförmåga och förhållningssätt följer som en konsekvens av att studenten tillgodogjort sig ämnesrelaterade faktakunskaper och metoder, i linje med Blooms taxonomi (Bloom \& Krathwohl, 1956). Men kausaliteten är inte självklar eftersom kunskapskategorierna är kvalitativt olika och kräver delvis olika läraktiviteter. Elmgren och Henriksson (2010) argumenterar istället för att även de mer komplexa kunskapskategorierna bör introduceras tidigt i utbildningen. Oavsett hur läraktiviteter struktureras för att stötta studenternas lärande handlar det om planerad progression (Fraser \& Bosanquet, 2006; Barnett, 2009), om "att kunskaper och färdigheter från tidigare kurser tas tillvara" (Elmgren \& Henriksson, 20IO, s. 140). Hur den ordningen bör konstrueras i vårt samhällsplanerarprogram är inte självklart.

En förklaring till det är själva huvudområdet. Kulturgeografi handlar om rumslig lokalisering - var människor och företeelser finns, men också om relationer och flöden dem emellan. Det handlar om landskap (t.ex. land-stad), människor (från individuella beslut och handlingar till globala flöden) och deras artefakter (t.ex. materiella och kulturella). Ämnet spänner därför över skilda ontologier - det materiella kombineras med det kulturella eller sociala i frågor av exempelvis ekonomisk, social eller politisk art (Gren $\&$ Hallin, 2003). För att hantera det tänker och verkar kulturgeografer ofta över kunskapsmässiga gränser och har en: "öppenhet gentemot idéer från andra ämnen [med] fokus på att integrera och skapa synteser" (Agnew m.fl., 1996, s. 2, min översättning). Kulturgeografi beskrivs ibland som just ett syntesämne eller en hopfogningslära (Gren \& Hallin, 2003).

Att systematiskt ta tillvara kunskaper från tidigare kurser innebär därför att successivt täcka av ämnets olika fält (ekonomisk geografi, social geografi och så vidare) och att utveckla den breda teori- och metodrepertoar som kännetecknar ämnet.

\section{METOD}

Ansatsen för den här studien inspireras av Cousins (2009, s. 155) beskrivning av "action research", aktionsforskning. Ansatsen används för att undersöka förändring i vardagliga, existerande verkligheter snarare än i kontrollerade sammanhang. Den syftar till att skapa nya förståelser 
och sätt att göra, den är handlingsinriktad. Metodansatsen är bred och bygger på ett iterativt, reflekterande och cykliskt arbetssätt (Cousins, 2009).

Den analys som redovisas här är grundad i en vardaglig verksamhet, den verksamhet där jag själv är lärare och studierektor. Analysen har växt fram ur undervisningsrelaterade aktiviteter och det är därför våra egna kurser som granskas. Det innebär att jag ställer frågor vars svar potentiellt kan utveckla min och mina kollegors förståelse av vår verksamhet, och därmed bidra till förändringar i verksamheten. Cousins (2009) kallar denna möjlighet till förändring för aktionsforskningens transformativa potential.

Valet att analysera samhällsplanerarprogrammet hänger samman med dess kontinuitet och stabilitet över tid i programstruktur och innehåll. Programmet fungerar. Valet förklaras också av att planering är en mångdimensionell aktivitet med avgörande inflytande på människor och verksamheter (Healey, 20ıо). Planering behöver därför utföras med bästa möjliga kompetens och kunnande.

Analysen bygger i huvudsak på empiriskt material i form av utbildningsplanen för samhällsplanerarprogrammet, kursplaner för samtliga kurser inom programmet och även scheman och övningsuppgifter. Allt underlagsmaterial gäller program och kurser för läsåret 20I4-20I5. Ambitionen är att tydliggöra helheten vad gäller programmets FSR, examinationsformer och i någon mån dess läraktiviteter.

Under vårterminen 20I4 genomförde lärarna i kulturgeografi en gemensam kategorisering av FSR på de kurser som ägdes av kulturgeografi och ingick i något av våra utbildningsprogram på grund- och avancerad nivå. De täckningsmatriser (Lucander \& Löfström, 20I4), det vill säga hur väl kursernas FSR matchade de nationella examensmålen, som växte fram föranledde revideringar av kursplaner inklusive reviderade kunskapsmål.

Det analysarbete som rapporteras här inleddes hösten 2014 med ett pedagogiskt seminarium där syfte och frågeställningar presenterades för lärarkollegiet och där den programansvarige gav sitt samtycke till analysen. De lärare som var kursansvariga informerades i februari $2015 \mathrm{om}$ analysen. Under våren försågs jag med samtliga scheman och övningsuppgifter från respektive kurs, det vill säga en del av det empiriska underlaget.

Den andra väsentliga delen av empirin utgörs av intervjuer med de fem lärare som under läsåret 20I4-20I5 var kursansvariga för någon av programmets kurser med FSR i kategorin värderingsförmåga och förhållningssätt (se figur 3). Intervjuerna baserades på konkreta frågor om varför kursens FSR finns med i kursplanen och hur de examineras, vilka typer av läraktiviteter som kopplas till de aktuella FSR:en och på vilka sätt de stöder måluppfyllelsen.

De minnesanteckningar som växte fram under intervjuerna renskrevs i detaljerade referat och stämdes av med respektive intervjuperson inom någon timme efter intervjutillfället. Referaten föranledde inga eller endast begränsade revideringar. Analysen av referaten skedde utifrån teman hämtade från studiens frågeställningar - innehåll i FSR, former för examination, läraktiviteter och så vidare.

\section{SAMHÄLLSPLANERARPROGRAMMET}

Samhällsplanerarprogrammet innehåller I3 kurser - nio som ägs av kulturgeografi, fyra som ägs av andra ämnen (figur I). Sett till fördelningen av högskolepoäng examinerar kulturgeografi 75 procent. 


\begin{tabular}{llcc}
\hline Termin & Kursens namn & Omfattning, högskolepoäng & Huvudområde, kursansvarig \\
\hline I & Ekonomisk och politisk geografi & I5 hp & Kulturgeografi \\
& Befolkningsgeografi & I5 hp & Kulturgeografi \\
2 & Samhällsplanering & I5 hp & Kulturgeografi \\
& Offentlig förvaltning och planering & $7,5 \mathrm{hp}$ & Statsvetenskap \\
& Arbetsmarknad och försörjning & $7,5 \mathrm{hp}$ & Nationalekonomi \\
3 & Ekologi och energi i planeringen & I5 hp & Biologi \\
4 & Kulturgeografiska metoder & I5 hp & Kulturgeografi \\
4 & GIS och rumslig analys & I5 hp & Kulturgeografi \\
5 & GIS, mobilitet och system & I5 hp & Kulturgeografi \\
& Fysisk infrastruktur och & I5 hp & Kulturgeografi \\
& detaljplanering & & \\
6 & Beteende och estetik i planeringen & I5 hp & Industridesign \\
& Planeringsteori och planerarrollen & I5 hp & Kulturgeografi \\
& Examensarbete i kulturgeografi & I5 hp & Kulturgeografi \\
\hline
\end{tabular}

Källa: Utbildningsplan 20I5, samtliga kursplaner som ingår i programmet

Fig 1. Sambällsplanerarprogrammets kurser, deras omfattning och huvudområdestillhörighet, läsairet 20I4-20I5.

En kortfattad beskrivning av programmets struktur är att de sex första kurserna i huvudsak rör ämneskunskaper, det vill säga betoning på kunskap och förståelse. Större delen av andra året på programmet är metodinriktat, med betoning på geografiska informationssystem (GIS). Där utvecklas i huvudsak studenternas ämnesrelaterade färdigheter och förmågor. Det tredje årets kurser fördjupar kunskapen och förståelsen och tillämpar metoder i projekt- och uppsatsarbeten. Den näst sista kursen på programmet fokuserar mer specifikt på planerarrollen och den kommande yrkesverksamheten. Examensarbete avslutar programmet.

Samhällsplanerarprogrammets samtliga FSR placerades in i högskoleförordningens tre kunskapskategorier i en täckningsmatris. Fördelningen visas i aggregerad form i figur 2.

I kunskapskategorin kunskap och förståelse finns 39 procent av programmets FSR. Övriga FSR fördelas om 50 procent $\mathrm{i}$ kategorin färdighet och förmåga samt elva procent $\mathrm{i}$ kategorin värderingsförmåga och förhållningssätt. Inom kunskapskategorin färdighet och förmåga är mer än hälften av kursernas FSR kopplade till det nationella målet att "visa förmåga att söka, samla, värdera och kritiskt tolka relevant information i en problemställning samt att kritiskt diskutera företeelser, frågeställningar och situationer" (SFS I993:I00, bilaga 2).

Samtliga kurser inom programmet innehåller FSR i de två första kunskapskategorierna. Däremot innehåller inga av de kurser som ges i andra huvudområden än kulturgeografi FSR i kategorin värderingsförmåga och förhållningssätt. Kurserna i övriga huvudområden lämnas därför utanför den fortsatta analysen. I figur 3 redovisas fördelningen av FSR på de nio kurser inom programmet som ägs av kulturgeografi. Kurserna redovisas i den ordning de ges inom programmet.

Två iakttagelser kan göras kring fördelningen av FSR i kurserna i kulturgeografi. Den ena är att mål för kunskap och förståelse samt färdighet och förmåga finns i samtliga kurser. Den andra är att FSR som gäller värderingsförmåga och förhållningssätt i huvudsak förekommer under den senare delen av programmet. 
Högre utbildning 91

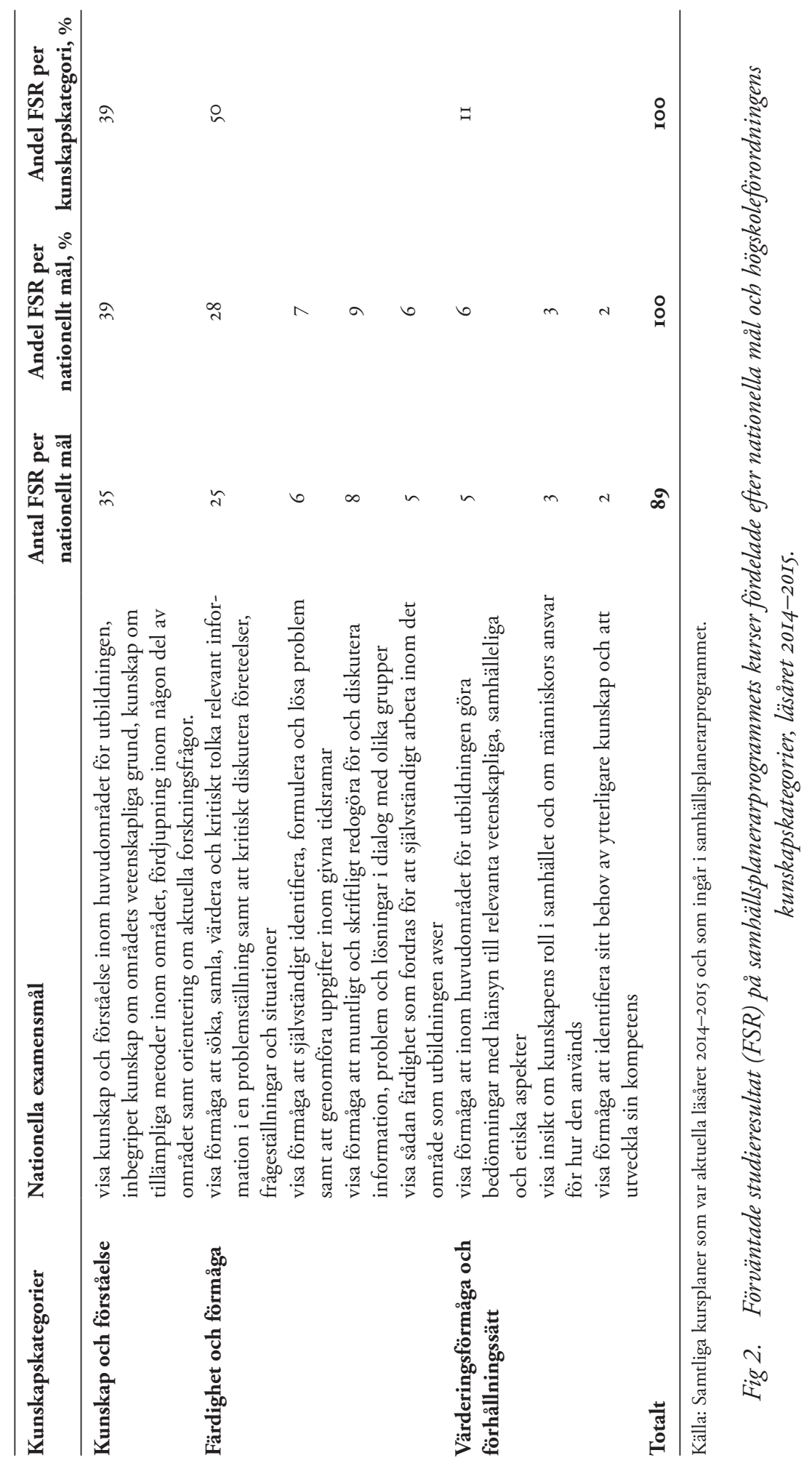




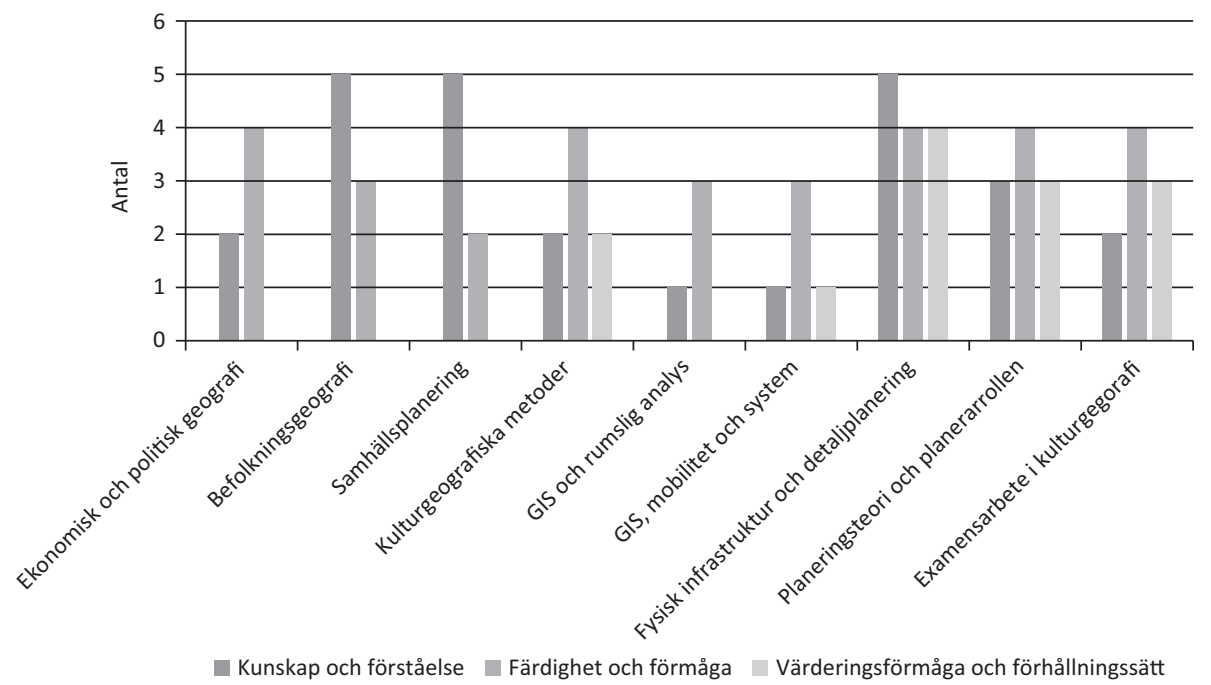

Källa: Samtliga kursplaner i kulturgeografi som var aktuella läsåret 20I4-20I5 och som ingår i samhällsplanerarprogrammet

Fig 3. Antal mål per kunskapskategori på de kulturgeografikurser som ingår i sambällsplanerarprogrammet, läsåret 20I4-20I5..

Läraktiviteterna på kurserna som ägs av kulturgeografi har kategoriserats efter Elmgren och Henriksson (20IO). Av schemalagda läraktiviteter på de nio kurserna utgör cirka en tredjedel föreläsningar, ytterligare en tredjedel utgörs av seminarier (ofta examinerande) och övningar (färdighetsträning). Studiebesök och exkursioner samt hemtentor utgör också en dryg tredjedel av schemalagd tid. Resterande inslag utgörs av stand by-handledning, frågor inför tentamen och liknande. Totalt utgör den schemalagda undervisningen på samhällsplanerarprogrammet ungefär 20 procent av tre års heltidsstudier.

\section{VÄRDERINGSFÖRMÅGA OCH FÖRHÅLLNINGSSÄTT PÅ \\ SAMHÄLLSPLANERARPROGRAMMET}

Elva av samhällsplanerarprogrammets FSR handlar om värderingsförmåga och förhållningssätt. De redovisas i det följande utifrån Campbells (20I2) fyra kunskapsformer, deskriptiv-preskriptiv och analytisk-normativ. Även om de förs till en kunskapsform här så rör sig lärare och studenter mellan de olika kunskapsformerna i läraktiviteter och examinationer. För att spåra den planerade progressionen presenteras kursernas FSR programkronologiskt inom respektive kategori. Redovisningen baseras på kursplaner, övnings- och examinationsinstruktioner samt intervjuer med respektive kursansvarig.

\section{Deskriptiv kunskap}

På programmets sista termin och kursen "Planeringsteori och planerarrollen" möter studenterna FSR:et att analysera arbetsmarknadens efterfrågan på sambällsplanerare samt formulera och presentera en CV. Läraktiviteterna som är kopplade till FSR:et består av tre föreläsningar med övningar som ska utveckla den egna förståelsen för det väntande yrkeslivet och att förbereda sig för det. Föreläsningarna ges av universitetets stödfunktion för externa relationer. Det ingår dock ingen egentlig analys av arbetsmarknaden och det finns heller ingen formell examination av detta FSR. 


\section{Preskriptiv kunskap}

Preskriptiv kunskap hänger samman med den deskriptiva i så måtto att det utifrån vetskapen om hur något är så kan handlingsinriktade förslag presenteras (Campbell, 20I2). Det sker tydligast under termin fem genom kursen "Fysisk infrastruktur och detaljplanering". Den innehåller ett stort antal gästföreläsningar med verksamma planerare och planeringsforskare, men också litteraturseminarier, studiebesök, övningar och ett större projektarbete.

Ett av kursens två FSR i kategorin värderingsförmåga och förhållningssätt är att studenterna ska visa förmåga att på ett kritiskt sätt förhålla sig till planeringsteorier och planeringsideal, samt att kunna omsätta detta i en konkret planeringssituation. FSR:et examineras genom ett projektarbete där studenterna ska ta fram ett detaljplaneprogram för ett tänkt framtida bostadsområde. Förslaget utsätts för granskning av medstudenterna och kräver argument baserade bland annat i planeringsteori.

På samma kurs finns även FSR:et att visa förmåga att identifiera behov av ytterligare underlag och kompetens för att lösa en given planeringsuppgift. Det examineras genom samma projektarbete. Studenterna ska enligt den kursansvariga "reflektera över det i sitt pm. Det handlar om att lösa uppgiften utifrån den egna förmågan och det de kan ta reda på. Utöver det ska de redovisa och diskutera vilka kunskaper och underlag som också hade behövts. De ska skriva fram det."

\section{Analytisk kunskap}

Programmets termin tre avslutas med kursen "Kulturgeografiska metoder" som består av två moment, kvantitativa och kvalitativa metoder. Vid kursens slut ska studenterna ha visat förmåga att kritiskt granska en kvalitativ studie. Tre övningar genomförs som innebär att I) pröva på själva hantverket att intervjua, 2) beskriva, analysera och diskutera användningen av kvalitativ metod i en vetenskaplig artikel och 3) genomföra en textanalys med ett avslutande seminarium. Enligt övningsinstruktionerna ska diskussionen vid seminariet: "i första hand fokusera på metodologiska frågor om tolkning, analys och reflexivitet, och i andra hand på ämnesfrågor". Metoden ska presenteras utförligt och de viktigaste aspekterna i redovisningen handlar om den egna analys- och tolkningsprocessen. Studenterna ska också granska och opponera på en annan students analys samt vara diskutand på ytterligare två.

Den kursansvariga läraren förklarar målsättningen med examinationen och det relaterade FSR:et:

Studenterna tränas i att värdera forskning, att granska akademiska texter. I praktiken innebär det att de opponerar på varandras slut-pm på moment två på kursen. Det är också en förberedelse för uppsatskursen, att avdramatisera oppositionen. Genom att granska andras arbete kan de förhoppningsvis också se sitt eget arbete på annat sätt.

Det hela är, enligt den kursansvariga, "en övning i akademisk seminariekultur". FSR:et examineras genom det seminarium som beskrevs ovan.

Ytterligare ett FSR - att ha uppvisat förmåga att förhälla sig reflexivt till den egna analysen och tolkningen samt den egna rollen i forskningsprocessen - examineras genom textanalysövningen. Särskilt betonas att studenterna ska kunna relatera sin egen och andras tolkningar mot varandra. Där är reflexiviteten är helt central. 
Efter metodkursen läser studenterna en termin GIS, geografiska informationssystem, uppdelat på två kurser om vardera Is hp. Båda kurserna använder enskilda övningar och tentamen som examinationsform. På den första kursen genom salstentamen; på den andra kursen - "GIS, mobilitet och system" - används hemtentamen för att examinera kursens FSR att tillämpa sina kunskaper $i$ GIS för kvalificerat utredningsarbete. Utifrån en given målvariabel ska studenterna visa att de kan hantera programvara, rumsliga data och rumslig teori. Av samtliga examinationer under terminen ställer den avslutande hemtentamen störst krav på självständighet i att utforma och genomföra en analys.

På kursen "Fysisk infrastruktur och detaljplanering" ska studenterna visa förmåga att analysera och kritiskt kommentera ett befintligt plandokument. Examinationen består av att studenterna ska analysera och diskutera konflikter relaterade till användning av strandnära miljöer. I instruktionen framgår att det kräver studier av planeringsdokument.

Kursen "Planeringsteori och planerarrollen" på termin sex är den sista före examensarbetet. Där finns ett FSR som är att tillämpa genusperspektiv på aktuella sambällsplaneringsprocesser. Genusfrågorna är integrerade i kursens undervisning, men perspektivet är för smalt, enligt den kursansvariga, särskilt som kvinnor ofta förstås som en homogen, vit grupp. De finns representerade i planeringsverksamheter. Andra grupper som barn eller invandrare är inte det. Kurslitteratur och föreläsningar tar upp dessa mer komplexa perspektiv. FSR:et examineras genom kursens projektarbete som handlar om platsers betydelser för olika grupper, om inkludering, exkludering och tillgänglighet i staden.

Samma kurs har FSR:et att reflektera över sin egen roll $i$ sambällsplaneringsprocessen. Det examineras också genom projektarbetet där studenterna skriver om den egna rollen. De ska då också reflektera över samhällsplaneringens uppdrag, möjligheter och begränsningar.

Den avslutande kursen på samhällsplanerarprogrammet är "Examensarbete i kulturgeografi". Där finns ett FSR som lyder: reflektera över egna resultat och kunskaper utifrän det problem och syfte som formulerats $i$ uppsatsen. Under kursen skrivs en uppsats, som enligt den kursansvariga ska visa något annat än tidigare kursers arbeten:

Uppsatsen beskriver jag ibland [för studenterna] som kronan på verket, och då är det rimligt att ha reflekterande kunskapsmål. I de kurser som föregår uppsatsen är kunskapsmål i de två andra kunskapskategorierna vanligare. Uppsatsen är något mer, där måste studenterna utöva självständighet och det förutsätter reflektion över det man gör och åstadkommer. I uppsatsen ska man utnyttja alla delar av sin utbildning för att skapa något självständigt.

Det lärandestöd studenterna ges sker i första hand genom individuell handledning. Kursens FSR examineras genom en uppsats, mer specifikt genom de diskuterande inslagen i uppsatsen.

\section{Normativ kunskap}

På kursen "Fysisk infrastruktur i detaljplaneringen", termin fem, finns FSR:et att visa förmåga att diskutera de avvägningsproblem mellan ambitioner och förutsättningar som ofta finns inbyggda i ett planärende. Den kursansvariga berättar:

I mångt och mycket bidrar gästföreläsarna med illustrativa exempel. Hur går planering till rent praktiskt? Var börjar och var slutar en planprocess? Vilka problem stöter man på? [...] Igen så ingår ju detta i projektarbetet, det examineras genom pm och redovisning vid seminarium. I handledningen som hör till projektarbetet handlar det ofta om de här sakerna. [Studenterna diskuterar:] "Hur ska vi göra? Vi tänkte så här! Eller så kan vi göra så här!” 
Värderingsförmåga och förhållningssätt - progression inom programmet

Den deskriptiva kunskapsformen ges litet utrymme i de FSR som handlar om värderingsförmåga och förhållningssätt. Det enda FSR som finns handlar inte egentligen om kapaciteten att planera.

De två FSR som definieras som preskriptiva är tydligt handlingsinriktade. Studenterna förväntas visa att de har förmåga att omsätta kunskaper $\mathrm{i}$ (planerad) handling. Båda FSR:en finns på samma kurs och examineras genom samma projektarbete, om än i olika avseenden. Det finns en viss progression i så måtto att studenterna rimligtvis skriver fram sina förslag utifrån minst två perspektiv, dels utifrån det de vet, dels utifrån att de ska identifiera kunskapsluckor i underlagen för detaljplaneprogrammet.

De FSR som tydligast förväntas stimulera studenternas analytiska kapacitet är flest till antalet och finns på samtliga fem kurser med FSR i kategorin värderingsförmåga och förhållningssätt. Tematiken består i huvudsak av dels en kritisk granskning av planeringstexter och -dokument, dels ett reflexivt förhållningssätt till det egna analysarbetet. Här finns en planerad progression på så sätt att studenterna ges upprepade möjligheter till kritisk granskning och reflexivitet.

Normativa kunskaper tillämpas i praktisk planering. Det FSR som tydligast ansluter till kunskapsformen finns på den kurs som tydligast tränar studenterna i handling. På den kursen kommer de närmast den "practical reasoning" som bidrar till att mejsla fram handlingsinriktade synteser.

\section{SLUTSATSER OCH DISKUSSION}

Den planerade progressionen inom samhällsplanerarprogrammet sker utifrån en bred bas av kunskap och förståelse. Under de tre första terminerna förmedlas i huvudsak kulturgeografiska ämneskunskaper som kompletteras med statsvetenskap, nationalekonomi, ekologi och naturgeografi. Inslag av färdighet och förmåga ingår under de inledande terminerna, men finns främst i metodundervisningen som utgör stora delar av programmets andra år. Åtta av programmets elva FSR i kunskapskategorin värderingsförmåga och förhållningssätt finns på kurser under programmets sista år. Studenternas förmåga att tillämpa vetenskapliga teorier, göra avvägningar och aktivt reflektera över yrkesrelaterade värden och handlingar examineras alltså i huvudsak mot slutet av samhällsplanerarprogrammet.

Läraktiviteterna i programmet domineras av föreläsningar, seminarier och övningar. Det finns ingen avgörande skillnad mellan de kurser som har FSR för att utveckla värderingsförmåga och förhållningssätt och övriga kurser vad gäller läraktiviteternas form, utöver den individuella handledningen under examensarbetet.

De examinationsformer som används för att bedöma uppfyllelsen av FSR i kategorin värderingsförmåga och förhållningssätt betonar hög grad av självständighet. Studenterna ska granska vetenskapliga texter, skriva och presentera egna texter samt kritiskt granska medstudenternas arbeten, presentera och diskutera vid seminarier samt göra bruk av sina metodfärdigheter.

Utvecklingen av deskriptiva och preskriptiva kunskaper sker i högre utsträckning inom ramen för de två första av högskoleförordningens kunskapskategorier, kunskap och förståelse samt färdighet och förmåga. FSR i kategorin värderingsförmåga och förhållningssätt stärker i huvudsak den analytiska kunskapsformen. Analytiska FSR introduceras under termin tre, de mer reflekterande under termin fem. De är alltså placerade mot slutet av programmet. Detsamma gäller på kursnivå, tydligast under de terminslånga studierna i GIS där den avslutande hemtentamen examinerar det GIS-relaterade FSR som handlar om värderingsförmåga och förhållningssätt.

Det finns däremot ingen planerad progressionen vad gäller normativa kunskaper. De kunskaperna examineras endast under en kurs. 
Är vår version av progression i programmet ett problem? Det uppenbara svaret är - nej. Alumnstudenterna rankar bredden som programmets viktigaste kvalitet, och de rankar utbildningen som den viktigaste förklaringen till de anställningar de fått (Lindström \& Mackay, 20I4). Examen från programmet ger dem tillträde till arbetsmarknaden. De närmar sig därmed professionen kunskapsmässigt och börjar utveckla en professionell identitet under utbildningen (Hoch, 1992; Smeby, 2007; Reid m.fl., 2008; Trede m.fl., 2012).

Finns det ändå ett värde i en analys av det här slaget? Det viktigaste motivet är att den ger möjlighet att värdera utbildningen i relation till övergripande mål och ambitioner av skilda slag. I vårt fall visar det sig att målstrukturen är ändamålsenlig i relation till studenternas anställningsbarhet. Studenterna kan också framgångsrikt konkurrera om platser på utbildningsprogram på avancerad nivå (Lindström \& Mackay, 20I4). Det som däremot görs tydligt i denna analys är att särskilt de normativa kunskaperna saknar explicit progression. Eftersom vi själva ger nio av tretton kurser inom programmet finns naturligtvis inga bra skäl till det förhållandet.

Insikten öppnar upp för pedagogisk utveckling. I vårt fall skulle det kunna medföra att vi utvecklar FSR, examinationer och läraktiviteter i befintliga kurser för att återkommande utveckla studenternas värderingsförmåga och förhållningssätt. Att integrera värderingsförmåga och förhållningssätt med inslag i utbildningen som handlar om kunskap och förståelse bör kunna stärka studenternas kritiska tänkande och inspirera till mer djupinriktat lärande. Analysen kan också motivera nya kursinslag, moment eller helt nya kurser. Ett tänkbart inslag skulle kunna vara att ge studenterna möjlighet att aktivt analysera och ge förslag till planeringsåtgärder i ett pågående planeringsärende. Autenticiteten i ett sådant inslag ger rimligtvis goda möjligheter att praktisera normativa kunskaper - att ge svar på frågan vad som borde göras i det enskilda fallet. Vi ger också ett kandidatprogram i kulturgeografi med inriktning turism. I den förestående revideringen av programmet kommer analyser av måluppfyllelse och progression att göras för att ge underlag för programmets ändrade utformning.

En annan tankegång är möjlig. Programmets totala schemalagda tid för läraktiviteter, i huvudsak lärarledda, uppgår till 20 procent av tre års heltidsstudier. Den absoluta merparten av utbildningen utgörs alltså av studenternas egna läraktiviteter. Även om de delvis styrs av examinationer och arbetsuppgifter på kurserna, så är institutionens inflytande över studenternas tidsanvändning begränsad. I det perspektivet kan den planerade progressionen förstås som ett bidrag till att skapa en studiegång som på bästa sätt motiverar till ämnesrelevanta självstudier.

\section{FÖRFATTARPRESENTATION}

Lars Larsson är filosofie doktor och lektor i kulturgeografi samt studierektor för grundutbildningen i samma ämne vid Umeå universitet. Min undervisning och forskning handlar i huvudsak om planering och turism, men i ökande utsträckning också om pedagogik och lärande.

\section{REFERENSER}

Agnew, J., Livingstone, D. N. \& Rogers, A. (Eds.). (1996). Human Geography: An Essential Anthology. Malden, MA: Blackwell Publishing.

Arnstein, S. R. (1969). A ladder of citizen participation. Journal of the American Institute of Planners, 35:4, 216-224.

Barnett, R. (1997). Higher education: A critical business. Buckingham: Open University Press.

Barnett, R. (2009). Knowing and becoming in the higher education curriculum. Studies in Higher Education, 34:4, 429-440. 
Berger, S. \& Forsberg, G. (red.). (2013). Planeringens utmaningar och tillämpningar. Stockholm: Liber.

Bloom, B. S. \& Krathwohl, D. R. (1956). Taxonomy of educational objectives: The classification of educational goals, by a committee of college and university examiners. Handbook I: Cognitive domain. New York: Longmans.

Campbell, H. (2006). Just planning: The art of situated ethical judgment. Journal of Planning Education and Research, 26:1, 92-106.

Campbell, H. (20I2). Planning to change the world: Between knowledge and action lies synthesis, Journal of Planning Education and Research, 32:2, I35-I46.

Cousins, G. (2009). Researching learning in higher education: An introduction to contemporary methods and approaches. New York, NY: Routledge.

Elmgren, M. \& Henriksson, A-S. (2010). Universitetspedagogik. Stockholm: Norstedts.

Fischler, R. (2012). Fifty theses on urban planning and urban planners. Journal of Planning Education and Research, 32:I, I07-II4.

Fraser, P. F. \& Bosanquet, M. B. (2006). The curriculum? That's just a unit outline, isn't it? Studies in Higher Education, 31:3, 269-284.

Gren, M. \& Hallin, P-O. (2003). Kulturgeografi: en ämnesteoretisk introduktion. Malmö: Liber.

Healey, P. (20I0). Making Better Places: The Planning Project in the Twenty-First Century. London: Palgrave Macmillan.

Hoch, C. J. (1992). The paradox of power in planning practice. Journal of Planning Education and Research, II:3, 206-2I5.

Innes, J. E. (1998). Information in communicative planning. Journal of the American Planning Association, 64:I, 52-63.

Lindström, I-M \& Mackay, H. (20I4). Alumnstudie 20I4, Institutionen för geografi och ekonomisk historia, Umeå universitet. Opublicerad.

Lucander, H. \& Löfström, G. (20I4). Genomlysning av kvalitet med avseende på bedömning genom utbildningsprogram mot en examen. Arbetsmaterial inför rapport avseende projektet - Kvalitetsutvärdering - bedömning, Malmö högskola. Opublicerad.

Lucas, U. \& Tan, P. L. (20I3). Developing a capacity to engage in critical reflection: students' 'ways of knowing' within an undergraduate business and accounting programme. Studies in Higher Education, 38:I, IO4-I23.

Luukkonen, J. (20II). The Europeanization of regional development: Local strategies and European spatial visions in Northern Finland. Geografiska Annaler: Series B, Human Geography, 93:3, 253-270.

Olsson, G. (1990). Antipasti. Göteborg: Bokförlaget Korpen.

Ramsden, P. (2003). Learning to Teach in Higher Education. London/New York: RoutledgeFalmer.

Reid, A., Dahlgren, L. O., Petocz, P. \& Abrandt Dahlgren, M. (2008). Identity and engagement for professional formation. Studies in Higher Education, 33:6, 729-742.

SFS 1993:I00 Högskoleförordningen.

Smeby, J. C. (2007). Connecting to professional knowledge. Studies in Higher Education, 32:2, 207-224.

Trede, F., Macklin, R. \& Bridges, D. (2012). Professional identity development: A review of the higher education literature. Studies in Higher Education, 37:3, 365-384. 